\title{
Relationship between Self-Care and Hand Foot Syndrome Specific Quality of Life in Cancer Patients
}

\author{
Naoko Mikoshiba $^{{ }^{*}}$, Noriko Yamamoto-Mitani ${ }^{1}$, Kazuki Sato ${ }^{2}$, Yukari Yaju ${ }^{3}$, \\ Mitsunori Miyashita ${ }^{2}$ \\ ${ }^{1}$ Department of Adult Nursing/Palliative Care Nursing, Graduate School of Medicine, The University of Tokyo, \\ Tokyo, Japan \\ ${ }^{2}$ Department of Palliative Nursing, Health Sciences, Tohoku University Graduate School of Medicine, Sendai, \\ Japan \\ ${ }^{3}$ Department of Nursing, St Luke's International University, Tokyo, Japan \\ Email: "naokom-tky@umin.ac.jp, noriko-tky@umin.ac.jp, kazukisato@med.tohoku.ac.jp,y-yaju@slcn.ac.jp, \\ miya@med.tohoku.ac.jp
}

Received 4 December 2015; accepted 15 February 2016; published 18 February 2016

Copyright (C) 2016 by authors and Scientific Research Publishing Inc.

This work is licensed under the Creative Commons Attribution International License (CC BY).

http://creativecommons.org/licenses/by/4.0/

(c) (i) 0 pen Access

\begin{abstract}
Purpose: The purpose of this study was to describe adherence to self-care for hand-foot syndrome (HFS) and the relationship between self-care and health-related quality of life (QOL). Methods: A cross-sectional study was conducted on 105 consecutive outpatients with HFS. To assess self-care for HFS and QOL, the participants were asked to complete self-care and HFS-14 (hand-foot syndrome specific QOL) questionnaires, respectively. Multiple regression models were used to identify the relationship between self-care and QOL. Results: Adherence to self-care for HFS was low, less than $50 \%$ for most of the items. Multivariate analysis revealed that poorer self-care $(\beta s=$ -0.19; $P=0.03)$, depressive symptoms $(\beta s=0.43 ; P<0.0001)$, and being employed $(\beta s=0.20 ; P=$ $0.04)$ were independent predictors of poorer QOL scores. Conclusions: We have identified a need for further research to develop effective programs of self-care in HFS.
\end{abstract}

\section{Keywords}

Chemotherapy, Hand-Foot Syndrome, Neoplasm, Quality of Life, Supportive Care

\footnotetext{
${ }^{*}$ Corresponding author.
}

How to cite this paper: Mikoshiba, N., Yamamoto-Mitani, N., Sato, K., Yaju, Y. and Miyashita, M. (2016) Relationship between Self-Care and Hand Foot Syndrome Specific Quality of Life in Cancer Patients. Open Journal of Nursing, 6, 100-109. 


\section{Introduction}

Hand-foot syndrome (HFS) is a common result of adverse effects of anti-cancer agents. It is characterized by dysesthesia and tingling of the palms, fingers, and soles [1]. The condition may progress over a few days, resulting in burning pain with diffuse erythema and swelling. In severe cases, there may be scaling, blistering, erosions, or ulcerations of the skin. The lesions can be very painful, and may interfere with even the simplest activities of daily living such as walking or gripping objects [1].

The drugs that most frequently cause HFS are pegylated liposomal doxorubicin [2], capecitabine [3] [4], sorafenib [5], sunitinib [6] and regorafenib [7]. The incidence of HFS in patients receiving these drugs is very high, exceeding 50\%. HFS is not life-threatening, but can seriously reduce QOL [8] [9]. Most reports describing patients with severe HFS indicate that this condition results in poor compliance with cancer treatment, or discontinuation of treatment [9]-[13].

While many side effects of chemotherapy are amenable to both pharmacologic and non-pharmacologic intervention, HFS is a side effect for which effective management continues to be sought. Randomized controlled trials have examined multiple agents for the prevention or treatment of HFS, including vitamin B6, steroid ointment, and celecoxib (a non-steroidal anti-inflammatory drug or NSAID) [14]-[16]. Some of these agents including celecoxib have demonstrated promising effects in subsets of patients [17], but require further research to substantiate preliminary findings. Research in non-pharmacologic intervention for the prevention or treatment of HFS is limited, resulting in an inability to establish effectiveness [18].

Recently, hydrocolloid dressings with a low-friction external surface, which are used for pressure ulcer care, have been reported to alleviate HFS pain [19]. Moisturizer has also been reported to alleviate HFS pain [20]. We have assumed that traditional self-care such as moisture retention (Patients should use moisturizer frequently, for example) or avoiding physical stimulus (Patients should avoid hot water, wear tight socks, and vigorous exercise, for example) may improve QOL by alleviating pain caused by HFS.

However, prior research has yet to describe the relationship between self-care and health-related quality of life in patients with HFS. Therefore, the purpose of this study is to evaluate adherence to self-care for HFS and to identify the relationship between self-care and QOL in patients with HFS.

\section{Methods}

\subsection{Data Collection}

This multi-centercross-sectional study was conducted from December 2012 to September 2013. Participants were selected from cancer patients who consecutively attended the outpatient clinic in Tokyo (The University of Tokyo Hospital, St Luke's International Hospital, Mitsui Memorial Hospital, and Kyoundo Hospital). The eligibility criteria were as follows: 1 ) age $>20$ years; 2) able to communicate in Japanese; 3) judged as able to participate in the study by an attending doctor; 4) receiving chemotherapy (capecitabine) or targeted therapy (sorafenib, sunitinib); 5) patients who had symptoms of HFS (CTCAE grade 1-3); and 6) consented to participation in the study. At the time of the study, pegylated liposomal doxorubicin and regorafenib were not available in Japan, so we did not include these agents. Patients who had symptoms of HFS were diagnosed by the medical staff. The severity of HFS was graded according to the CTCAE criteria: grade 0 , patients without HFS, grade 1, minimal skin changes or dermatitis (e.g., erythema, edema, hyperkeratosis) without pain; grade 2, skin changes (e.g., peeling, blisters, bleeding, edema, hyperkeratosis) with pain, limiting activities of daily living; or grade 3, severe skin changes (e.g., peeling, blisters, bleeding, edema, hyperkeratosis) with pain, limiting activities of daily living. Patients without evidence of HFS were excluded from the study. All the patients had been informed of the possibility and symptoms of HFS before the initiation of chemotherapy.

Patients self-administered the questionnaires. Medical data were collected by reviewing the medical records. The investigator checked for absent responses after receiving the questionnaire, and asked the patients to respond to missing items when possible. Ethics committee approval to conduct the study for all participating institutions was obtained.

\subsection{Measures}

On the basis of previous studies and expert opinion in oncology, we established a conceptual framework of pa- 
tient-related factors that were assumed to be associated with QOL and divided these factors into the following 4 categories: modifiable health behavior (self-care), clinical condition, psychological status, and sociodemographic factors. Details of these factors and our assumptions about their relationships with QOL are provided below.

\subsubsection{Measurement of Quality of Life}

HFS-14 is a self-administered questionnaire including 17 items that is specifically designed for assessment of QOL in patients with HFS [21]. Each item is scored on a three-point Likert scale: 0, "no, never"; 3, "yes, from time to time"; or 6, "yes, always". There is also a question to score limb involvement (1, only hands or only feet affected; or 3, hands and feet both affected), a question to score pain (1, not painful; 2, moderately painful; or 3, very painful), and a visual analog scale for pain (scored 0-10). The total score is calculated by summation of the item scores, with a maximum score of 100 and a minimum score of 2. A higher score indicates poorer QOL. The reliability and validity of the Japanese version of HFS-14 have been confirmed [22] (Appendix).

\subsubsection{Measurement of Self-Care for Hand-Foot Syndrome}

We developed a self-care scale on the basis of previous studies [15] [16] [18]. Content validity of the resulting questionnaire was confirmed by specialists in oncology and dermatology. Following a pilot test in ten patients, self-care for HFS was measured using an eight-item self-administered questionnaire with a 5-point ordinal scale ranging from 1 (not at all) to 5 (completely agree). The total score is calculated by summation of the item scores, with a maximum score of 40 and a minimum score of 8 . Higher scores indicate better self-care. Cronbach's alpha coefficient for this scale was 0.86 .

\subsubsection{Measurement of Depressive Symptoms}

Depressive symptoms were measured using the Japanese version of the Center for Epidemiologic Studies Depressive Symptoms Scale (CES-D). The CES-D is a 20-item self-report questionnaire designed for the screening of depressive symptoms. Scores for each item are summed to give a range of total scores from 0 to 60 . A higher score indicates a greater tendency toward depressive symptoms. A score of 16 points or higher suggests the presence of clinical depressive symptoms. The reliability and validity of the Japanese version of the CES-D have been confirmed. In the Japanese version [23], the cutoff value of 16 was also optimal, assessed by comparing the proportion of patients with CES-D scores of 16 points or higher in a normal control group with that in a group of patients with mood disorders.

\subsubsection{Sociodemographic Characteristics}

The following sociodemographic information was collected from the self-administered questionnaire: employment status, educational level, and cohabitant status.

\subsubsection{Clinical Characteristics}

The following clinical information was collected from the medical records of each patient: sex, age, type of cancer, Eastern Cooperative Oncology Group Performance Status (ECOG PS), anti-cancer agent, time since treatment, and grade of HFS. The severity of HFS was graded according to the Common Terminology Criteria for Adverse Events (CTCAE) criteria: grade 0, no signs or symptoms of HFS; Grade 1, minimal skin changes or dermatitis (e.g., erythema, edema, hyperkeratosis) without pain; Grade 2, skin changes (e.g., peeling, blisters, bleeding, edema, hyperkeratosis) with pain, limiting activities of daily living; or Grade 3, severe skin changes (e.g., peeling, blisters, bleeding, edema, hyperkeratosis) with pain, limiting activities of daily living.

\subsection{Statistical Analysis}

Descriptive statistics were used initially. In this study, we defined good adherence operationally as a score of 5 (5 is "I completely agree") or 4, and poor adherence as a score of 3, 2, or 1 (1 is "I do not agree at all"), for each item of the self-care scale. Bivariate analysis was performed to identify the factors associated with HFS-14 score using t-test, analysis of variance, or Spearman's rank correlation coefficient, where appropriate. After checking that there was no multicollinearity between the variables, multiple regression analysis was performed. Variables with a P value of 0.2 or less were included in a backward variable selection. Multicollinearity was assessed by 
correlation coefficients between variables and the variance inflation factor. For all statistical tests, $\mathrm{P}<0.05$ (two-sided) was regarded as statistically significant. All statistical analyses were performed using SAS, version 9.3 (SAS Institute Inc., Cary, NC, USA).

\section{Results}

\subsection{Study Flow and Response Rate}

Among 196 eligible patients, 9 refused to participate in the study (owing to lack of time). The remaining 187 patients from four centers were included in this study (response rate 95.4\%). Among 187 patients, 105 patients had CTCAE Grades 1-3 HFS (56.1\%). We analyzed the 105 patients with HFS.

\subsection{Characteristics of the Study Subjects}

The sociodemographic and clinical characteristics of the study subjects are shown in Table 1 . The mean age of patients with HFS was $62.3 \pm 12.0$ years, and most were living with family or other adults. Most subjects had good performance status (ECOG PS $0, \underline{\mathbf{7 7 . 1} \%})$ and CTCAE Grade 1 HFS $(\underline{\mathbf{6 3 . 8 \%}})$. The mean time since start of treatment with relevant drug was $4.6 \pm 5.7$ months.

\subsection{Adherence to Self-Care}

Table 2 shows the percentage of good adherence to self-care according to our operational definition. 5 of the 8

Table 1. Sociodemographic and clinical characteristics of the study subjects.

\begin{tabular}{|c|c|}
\hline & $\mathrm{n}(\%)$ \\
\hline Male gender & $55(52.4)$ \\
\hline Age, $\mathrm{y}^{*}$ & $62.3 \pm 12.0$ \\
\hline Employed fulltime or part-time & $38(36.2)$ \\
\hline \multicolumn{2}{|l|}{ Education } \\
\hline$\leq 12$ years & $70(66.7)$ \\
\hline Living with family or other adults & $99(94.3)$ \\
\hline \multicolumn{2}{|l|}{ Cancer type } \\
\hline Breast cancer & $35(33.3)$ \\
\hline Colorectal cancer & $30(28.6)$ \\
\hline Hepatocellular carcinoma & $31(29.5)$ \\
\hline Renal cell carcinoma & $9(8.6)$ \\
\hline \multicolumn{2}{|l|}{ ECOG performance status } \\
\hline 0 & $81(77.1)$ \\
\hline 1 & $23(21.9)$ \\
\hline 2 & $1(1.0)$ \\
\hline \multicolumn{2}{|l|}{ Anti-cancer agents } \\
\hline Capecitabine & $65(61.9)$ \\
\hline Sorafenib & $31(29.5)$ \\
\hline Sunitinib & $9(8.6)$ \\
\hline Time since start of treatment with relevant drug, month ${ }^{*}$ & $4.6 \pm 5.7$ \\
\hline \multicolumn{2}{|l|}{ CTCAE grade of HFS } \\
\hline Grade 1 & $67(63.8)$ \\
\hline Grade 2 & $36(34.3)$ \\
\hline Grade 3 & $2(1.9)$ \\
\hline
\end{tabular}

Values are numbers (\%) otherwise specified. "Data are expressed as mean (standard deviation). 
Table 2. Percentage of "good adherence" and mean scores on the self-care scale for each item.

\begin{tabular}{lcc}
\hline & Percentage of good adherence & Score of the self-care \\
\hline Frequent use of moisturizer & 75.2 & $4.2 \pm 1.1$ \\
Avoiding unnecessary walking, jogging, or vigorous exercise & 59.1 & $3.7 \pm 1.3$ \\
Avoiding tight socks & 50.5 & $3.6 \pm 1.2$ \\
Wearing soft shoes that fit one's feet & 37.2 & $3.1 \pm 1.3$ \\
Using soft sole insert or wearing sick socks & 33.3 & $3.1 \pm 1.2$ \\
Avoiding activities that cause rubbing of skin surfaces or even slight & 32.4 & $3.0 \pm 1.1$ \\
pressure on hands & 30.4 & $3.0 \pm 1.3$ \\
Avoiding exposure of hands and feet to heat such as hot water & 21.0 & $2.3 \pm 1.2$
\end{tabular}

The response to each item was scored between 1 (I do not agree at all) and 5 (I completely agree). In our study, patients were divided into 2 categories: either "good adherence" with a score of 4 or 5 , or "poor adherence" with scores of 1, 2, or 3.

self-care techniques had "good adherence" of less than 50\%. Item that avoiding exposure to sunlight, hands and feet to heat, rubbing of skin surface or even slight pressure on hands, using soft sole insert, and wearing soft shoes had scores lower than $50 \%$. The mean total self-care score was $25.8 \pm 7.5$.

\subsection{Self-Care and Quality of Life in Patients with HFS}

The results of bivariate analysis are shown in Table 3. Significant and negative associations were observed between self-care and HFS-14 score $(\rho=-0.21 ; \mathrm{P}=0.02)$. Other relevant clinical variables associated with poor quality of life (elevated HFS-14 scores) were: depressive symptoms $(\mathrm{P}<0.0001)$; having ECOG PS of $0(\mathrm{P}=$ $0.01)$; and being employed $(\mathrm{P}=0.03)$. The results of multivariate analysis are shown in Table 4. Self-care score $(\beta s=-0.19 ; \mathrm{P}=0.03)$ was an independent predictor of HFS-14 score. Depressive symptoms $(\beta s=0.43 ; \mathrm{P}<$ $0.0001)$ and being employed $(\beta s=0.20 ; \mathrm{P}=0.04)$ were also independent predictor s of HFS-14 score.

\section{Discussion}

Our study evaluated adherence to self-care for hand-foot syndrome and identified an association between selfcare and QOL in patients with hand-foot syndrome. The major findings of this study are as follows: 1) Adherence to self-care for HFS was low, less than 50\% with most of the items; and 2) level of self-care for hand-foot syndrome is an independent predictor of QOL in patients with hand-foot syndrome.

Adherence to self-care for HFS was low. This result is similar to previous studies in patients with HFS, which reported that patients showed poor self-care due to a lack of educational opportunities [24]. However, our study patients showed poor self-care despite receiving education. Low adherence to avoid hot water may be related to bath-loving Japanese cultural background. Low adherence to avoid sunlight may arise from a lack of knowledge, because few brochures write about avoiding sunlight. Avoiding pressure on hands may be hard, because we need to use hands for housekeeping and works. Programs for improving adherence to self-care are needed, in addition to providing knowledge and techniques of self-care for HFS.

Multivariate analysis revealed that self-care for HFS was an independent predictor of QOL. Traditional selfcare such as moisture retention or avoiding physical stimulus may improve QOL by alleviating pain caused by HFS. This study was a cross-sectional design, and therefore no causal relationship between self-care and QOL could be established. However, our results suggest the potential benefit of self-care.

It is noteworthy that depressive symptoms were an independent predictor of poorer HFS-specific QOL. The prevalence of depressive symptoms in this population (30.5\%) was slightly higher than that reported in a meta-analysis of the prevalence of depression in cancer patients (8\% - 24\%) [25]. It has been suggested that depressive symptoms strongly affect QOL [26] [27]. In many studies, a reciprocal interaction between somatic symptoms and depressive symptoms has been shown [28]. For example, there is higher risk of depressive symptoms in patients with uncontrolled pain and an enhanced perception of pain amongst depressed patients [29]. In addition, antidepressants have been shown to be effective as adjuvant therapy for several symptoms, such as pain, insomnia, and anorexia [30]. Our findings also suggest an association between depressive symptoms and decreased QOL in HFS patients. Fortunately, depressive symptoms are treatable. Numerous rando- 
Table 3. Univariate analysis for factors related to HFS-14 score.

\begin{tabular}{|c|c|c|c|}
\hline Variables & $\mathrm{N}(\%)$ or mean $\pm \mathrm{SD}$ & HFS-14 score (or $\rho$ ) & P-value \\
\hline \multicolumn{4}{|l|}{ Gender } \\
\hline Male & $55(52.4)$ & $20.3 \pm 18.3$ & 0.51 \\
\hline Female & $50(47.6)$ & $22.8 \pm 22.0$ & \\
\hline Age, $\mathrm{y}^{*}$ & $62.3 \pm 12.0$ & 0.05 & 0.60 \\
\hline \multicolumn{4}{|l|}{ Employment status } \\
\hline Employed & $38(36.2)$ & $27.6 \pm 24.1$ & 0.03 \\
\hline Unemployed & $67(63.8)$ & $18.0 \pm 16.6$ & \\
\hline \multicolumn{4}{|l|}{ Education } \\
\hline$\leq 12$ years & $70(66.7)$ & $22.7 \pm 20.9$ & 0.35 \\
\hline$>12$ years & 35 (33.3) & $19.1 \pm 18.2$ & \\
\hline \multicolumn{4}{|l|}{ Cohabitation status } \\
\hline Living with family or other adults & 99 (94.3) & $21.2 \pm 19.3$ & 0.67 \\
\hline Living alone & $6(5.7)$ & $27.0 \pm 31.9$ & \\
\hline \multicolumn{4}{|l|}{ ECOG performance status } \\
\hline 0 & $81(77.1)$ & $23.4 \pm 21.8$ & 0.01 \\
\hline 1 or 2 & $24(22.9)$ & $15.3 \pm 11.1$ & \\
\hline \multicolumn{4}{|l|}{ Type of cancer } \\
\hline Breast cancer & 35 (33.3) & $24.4 \pm 20.3$ & 0.22 \\
\hline Colorectal cancer & $30(28.6)$ & $15.5 \pm 13.1$ & \\
\hline Hepatocellular carcinoma & $31(29.5)$ & $22.2 \pm 25.0$ & \\
\hline Renal cell carcinoma & $9(8.6)$ & $27.8 \pm 17.5$ & \\
\hline \multicolumn{4}{|l|}{ Anti-cancer agent } \\
\hline Capecitabine & $65(61.9)$ & $20.3 \pm 17.8$ & 0.46 \\
\hline Sorafenib or Sunitinib & $40(38.1)$ & $23.5 \pm 23.5$ & \\
\hline Time since treatment, months ${ }^{*}$ & $4.6 \pm 5.7$ & 0.19 & 0.05 \\
\hline \multicolumn{4}{|l|}{ Depressive symptoms } \\
\hline Yes & $32(30.5)$ & $37.9 \pm 22.3$ & $<0.0001$ \\
\hline No & $73(69.5)$ & $15.5 \pm 15.5$ & \\
\hline Self-care score for hand foot syndrome & $25.8 \pm 7.5$ & -0.21 & 0.02 \\
\hline
\end{tabular}

Values are expressed as number (\%) unless otherwise specified.

*Data expressed as mean (standard deviation).

Higher HFS-14 scores indicate poorer QOL.

Higher ECOG performance status scores signify better performance status.

Higher self-care scores indicate better self-care.

\section{Table 4. Multiple regression analysis of factors relate to HFS-14 score.}

\begin{tabular}{ccc} 
Variable & $s \beta$ & P-value \\
\hline $\begin{array}{c}\text { Employment status } \\
\text { Employed } \\
\text { Unemployed (ref) }\end{array}$ & 0.20 & 0.04 \\
ECOG performance status & 0.08 \\
0 & 0.16 & 0.19 \\
1 or 2 (ref) & 0.11 & $<0.0001$ \\
Time since treatment, months & & 0.03 \\
Depressive symptoms & & 0.03 \\
Yes & & 0.19 \\
No (ref) & & 0.43 \\
\hline
\end{tabular}

$s \beta=$ standard partial regression coefficients.

Variables described were selected by backward methods $(\mathrm{P}<0.2)$.

Higher HFS-14 scores indicate poorer QOL.

Higher ECOG performance scores signify better performance status.

Higher self-care scores indicate better self-care. 
mized controlled trials show that psychological distress, including depressive symptoms, can be alleviated by pharmacologic and non-pharmacologic interventions [31]. Therefore, we may be able to alleviate pain and improve QOL of patients suffering from HFS by treating their depressive symptoms.

Interestingly, being employed was also significantly related to poorer QOL. Workers need to use their hands and feet more frequently, for computer work or commuting by foot and so on. These may afflict patients with HFS who need to work. Healthcare professionals need to support these patients individually depending on their content of work.

This study has several limitations. First, the patient population was relatively small and the patients were limited to outpatients at four hospitals in Tokyo. Self-care might vary under different circumstances or in different groups of patients. This point must be taken into consideration when interpreting our results, and further studies are necessary to address this limitation. Second, self-care for HFS was measured only by self-reporting. Nonadherence to treatment regimens might tend to be underreported and adherence might tend to be over-reported. Therefore, adherence as reported by patients may have been overestimated in our study. Finally, because of the cross-sectional nature of our survey, we could not test for a cause-effect relationship. Longitudinal studies would be required to establish that treating depressive and improving self-care would or would not have an effect on QOL.

\section{Conclusion}

This study investigated the level of adherence to self-care for HFS and the relationship between self-care and QOL in patients with HFS. Adherence to self-care for HFS was low, less than $50 \%$ for most of the items. Moreover, we found that self-care for HFS was an independent predictor of QOL. Depressive symptoms and being employed were also independent predictors of QOL. These findings emphasized the need to educate patients with HFS to take appropriate action if HFS worsened. Also, healthcare professionals should pay more attention to the possibility of decreased QOL among HFS patients who were employed or who had depressive symptoms.

\section{Acknowledgements}

This work was supported in part by a Third Term Comprehensive Control Research for Cancer grant from the Japanese Ministry of Health, Labour and Welfare [grant number 22092401]. The authors thank all the patients who took part in the study. The authors also thank Hiroyasu Esumi for his support.

\section{Conflict of Interest Statement}

The author did not have any potential conflicts of interest in the research reported.

\section{References}

[1] Common Terminology Criteria for Adverse Events (CTCAE) v4.0. 2011. http://ctep.cancer.gov/protocolDevelopment/electronic_applications/ctc.htm

[2] Fujisaka, Y., Horiike, A., Shimizu, T., Yamamoto, N., Yamada, Y. and Tamura, T. (2006) Phase 1 Clinical Study of Pegylated Liposomal Doxorubicin (JNS002) in Japanese Patients with Solid Tumors. Japanese Journal of Clinical Oncology, 36, 768-774. http://dx.doi.org/10.1093/jico/hyl109

[3] Hyodo, I., Shirao, K., Doi, T., et al. (2006) A phase II Study of the Global Dose and Schedule of Capecitabine in Japanese Patients with Metastatic Colorectal Cancer. Japanese Journal of Clinical Oncology, 36, 410-417. http://dx.doi.org/10.1093/jjco/hyl058

[4] Twelves, C., Wong, A., Nowacki, M.P., et al. (2005) Capecitabine as Adjuvant Treatment for Stage III Colon Cancer. New England Journal of Medicine, 352, 2696-704. http://dx.doi.org/10.1056/NEJMoa043116

[5] Robert, C., Mateus, C., Spatz, A., Wechsler, J. and Escudier, B. (2009) Dermatologic Symptoms Associated with the Multikinase Inhibitor Sorafenib. Journal of the American Academy of Dermatology, 60, 299-305. http://dx.doi.org/10.1016/j.jaad.2008.06.034

[6] Tomita, Y., Shinohara, N., Yuasa, T., et al. (2010) Overall Survival and Updated Results from a Phase II Study of Sunitinib in Japanese Patients with Metastatic Renal Cell Carcinoma. Japanese Journal of Clinical Oncology, 40, 11661172. http://dx.doi.org/10.1093/jjco/hyq146 
[7] Belum, V.R., Wu, S. and Lacouture, M.E. (2013) Risk of Hand-Foot Skin Reaction with the Novel Multikinase Inhibitor Regorafenib: A Meta-Analysis. Investigational New Drugs, 31, 1078-1086. http://dx.doi.org/10.1007/s10637-013-9977-0

[8] Nardone, B., Hensley, J.R., Kulik, L., et al. (2012) The Effect of Hand-Foot Skin Reaction Associated with the Multikinase Inhibitors Sorafenib and Sunitinib on Health-Related Quality of Life. Journal of Drugs in Dermatology, 11, e61-e65.

[9] Rivera, E., Valero, V., Syrewicz, L., et al. (2001) Phase I Study of Stealth Liposomal Doxorubicin in Combination with Gemcitabine in the Treatment of Patients with Metastatic Breast Cancer. Japanese Journal of Clinical Oncology, 19, 1716-1722.

[10] Azuma, Y., Hata, K., Sai, K., et al. (2012) Significant Association between Hand-Foot Syndrome and Efficacy of Capecitabine in Patients with Metastatic Breast Cancer. Biological and Pharmaceutical Bulletin, 35, 717-724. http://dx.doi.org/10.1248/bpb.35.717

[11] Gressett, S.M., Stanford, B.L. and Hardwicke, F. (2006) Management of Hand-Foot Syndrome Induced by Capecitabine. Journal of Oncology Pharmacy Practice, 12, 131-141. http://dx.doi.org/10.1177/1078155206069242

[12] Shahrokni, A., Rajebi, M.R. and Saif, M.W. (2009) Toxicity and Efficacy of 5-Fluorouracil and Capecitabine in a Patient with TYMS Gene Polymorphism: A Challenge or a Dilemma? Clinical Colorectal Cancer, 8, 231-234. http://dx.doi.org/10.3816/CCC.2009.n.039

[13] Park, Y.H., Ryoo, B.Y., Lee, H.J., Kim, S.A. and Chung, J.H. (2003) High Incidence of Severe Hand-Foot Syndrome during Capecitabine-Docetaxel Combination Chemotherapy. Annals of Oncology, 14, 1691-1692. http://dx.doi.org/10.1093/annonc/mdg446

[14] von Gruenigen, V., Frasure, H., Fusco, N., DeBernardo, R., Eldermire, E., Eaton, S. and Waggoner, S. (2010) A Double-Blind, Randomized Trial of Pyridoxine versus Placebo for the Prevention of Pegylated Liposomal Doxorubicin-Related Hand-Foot Syndrome in Gynecologic Oncology Patients. Cancer, 116, 4735-4743. http://dx.doi.org/10.1002/cncr.25262

[15] Anderson, R., Jatoi, A., Robert, C., Wood, L.S., Keating, K.N. and Lacouture, M.E. (2009) Search for Evidence-Based Approaches for the Prevention and Palliation of Hand-Foot Skin Reaction (HFSR) Caused by the Multikinase Inhibitors (MKIs). The Oncologist, 14, 291-302. http://dx.doi.org/10.1634/theoncologist.2008-0237

[16] Lassere, Y. and Hoff, P. (2004) Management of Hand-Foot Syndrome in Patients Treated with Capecitabine (Xeloda). European Journal of Oncology Nursing, 8, S31-S40. http://dx.doi.org/10.1016/j.ejon.2004.06.007

[17] Zhang, R.X., Wu, X.J., Wan, D.S., Lu, Z.H., Kong, L.H., Pan, Z.Z. and Chen, G. (2012) Celecoxib Can Prevent Capecitabine-Related Hand-Foot Syndrome in Stage II and III Colorectal Cancer Patients: Result of a Single-Center, Prospective Randomized Phase III Trial. Annals of Oncology, 23, 1348-1353. http://dx.doi.org/10.1093/annonc/mdr400

[18] von Moos, R., Thuerlimann, B.J., Aapro, M., Rayson, D., Harrold, K., Sehouli, J., et al. (2008) Pegylated Liposomal Doxorubicin-Associated Hand-Foot Syndrome: Recommendations of an International Panel of Experts. European Journal of Cancer, 44, 781-790. http://dx.doi.org/10.1016/j.ejca.2008.01.028

[19] Shinohara, N., Nonomura, N., Kimura, G., et al. (2013) A Randomized Multicenter Phase II Trial on Efficacy of a Hydrocolloid Dressing Containing Ceramide with a Low-Friction External Surface for Hand-Foot Skin Reaction Caused by Sorafenib in Patients with Renal Cell Carcinoma. Proceedings of the Annual Meeting of the American Society of Clinical Oncology, 31, abstr 9623.

[20] Ren, Z.G., Zhu, K.S., Kang, H.Y., Lu, M.Q., et al. (2012) A Randomized Controlled Phase II Study of the Prophylactic Effect of Urea-Based Cream on the Hand-Foot Skin Reaction Associated with Sorafenib in Advanced Hepatocellular Carcinoma. Proceedings of the Annual Meeting of the American Society of Clinical Oncology, 30, adstr 4008.

[21] Sibaud, V., Dalenc, F., Chevreau, C., Roché, H., Delord, J.-P., Mourey, L., et al. (2011) HFS-14, a Specific Quality of Life Scale Developed for Patients Suffering from Hand-Foot Syndrome. The Oncologist, 16, 1469-1478. http://dx.doi.org/10.1634/theoncologist.2011-0033

[22] Mikoshiba, N., Yamamoto-Mitani, N., Sato, K., Asaoka, Y., Ohki, T., Ohata, M. and Miyashita, M. (2015) Validation of the Japanese Version of HFS-14, a Disease-Specific Quality of Life Scale for Patients Suffering from Hand-Foot Syndrome. Supportive Care in Cancer, 23, 2739-2745.

[23] Shima, S., Shikano, T., Kitamura, T. and Asai, M. (1985) A New Self-Rating Scale for Depression. Japanese Journal of Clinical Psychiatry, 27, 717-723.

[24] Zhao, Y., Ding, Y., Lu, Y., Zhang, J., Gu, J. and Li, M. (2013) Incidence and Self-Management of Hand-Foot Syndrome in Patients with Colorectal Cancer. Clinical Journal of Oncology Nursing, 17, 434-437. http://dx.doi.org/10.1188/13.CJON.434-437

[25] Krebber, A.M., Buffart, L.M., Kleijn, G., Riepma, I.C., de Bree, R., Leemans, C.R., et al. (2014) Prevalence of Depression in Cancer Patients: A Meta-Analysis of Diagnostic Interviews and Self-Report Instruments. Psychooncology, 
23, 121-130.

[26] Skarstein, J., Aass, N., Fossa, S.D., Skovlund, E. and Dahl, A.A. (2000) Anxiety and Depression in Cancer Patients: Relation between the Hospital Anxiety and Depression Scale and the European Organization for Research and Treatment of Cancer Core Quality of Life Questionnaire. Journal of Psychosomatic Research, 49, 27-34. http://dx.doi.org/10.1016/S0022-3999(00)00080-5

[27] Saevarsdottir, T., Fridriksdottir, N. and Gunnarsdottir, S. (2010) Quality of Life and Symptoms of Anxiety and Depression of Patients Receiving Cancer Chemotherapy: Longitudinal Study. Cancer Nursing, 33, E1-E10. http://dx.doi.org/10.1097/NCC.0b013e3181b4adb5

[28] Bair, M.J., Robinson, R.L., Katon, W. and Kroenke, K. (2003) Depression and Pain Comorbidity: A Literature Review. Archives of Internal Medicine, 163, 2433-2445. http://dx.doi.org/10.1001/archinte.163.20.2433

[29] Gagliese, L., Gauthier, L.R. and Rodin, G. (2007) Cancer Pain and Depression: A Systematic Review of Age-Related Patterns. Pain Research \& Management, 12, 205-211.

[30] Riechelmann, R.P., Burman, D., Tannock, I.F., Rodin, G. and Zimmermann, C. (2010) Phase II Trial of Mirtazapine for Cancer-Related Cachexia and Anorexia. American Journal of Hospice and Palliative Medicine, 27, 106-110. http://dx.doi.org/10.1177/1049909109345685

[31] Li, M., Fitzgerald, P. and Rodin, G. (2012) Evidence-Based Treatment of Depression in Patients with Cancer. Journal of Clinical Oncology, 30, 1187-1196. http://dx.doi.org/10.1200/JCO.2011.39.7372 


\section{Appendix}

次の質問は, 手足症候群があなたの生活にどれくらい影響を与えたかについてお伺いするものです. 手足症候群 とは, 化学療法の副作用であり, 見た目の変化として手足の皮膚が赤くなったり, 水泡, ひび割れ, 皮がはがれたり, 硬くなったりし, 症状としてピリピリ, ひりひり, 感覚がいつもと違うなどから始まり, 進行すると痛みを生じ, ものがつ かめなくなったり歩くのが難しくなつたりする症候群といわれています. それぞれの質問で, 最もよくあてはまるもの に一つだけ○を付けてください.

手足症候群がある体の部分を具体的にお答えください
1. 手
2. 足
3. 手亡足
4.なし

ご自分の手足症候群に，次のような症状があると思われますか.

\section{1.とても痛い 2. . まあまあ痛い 3. 全く痛くない}

次の文章がご自分に当てはまるか, あまり深く考えず, できるだけ感じたようにお答えください. 正しい答 えや間違つた答え，というものはありません．ご自分の経験に基づいてご回答ください.

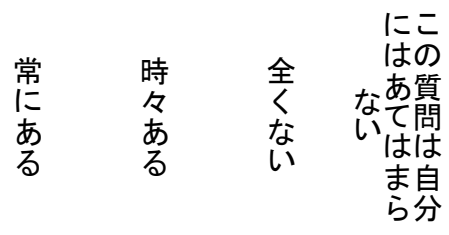

1. 手足症候群のために, ドアの鍵が回しにくい.

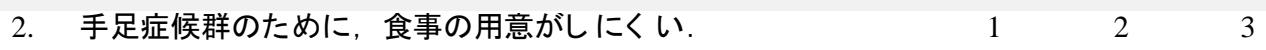

3. 手足症候群のために，＼cjkstart毎日の活動に支障がある.

4. 手足症候群のために，身体を洗ったり，化粧 またはひげ剃り） 1213 したりするのが難しい.

5. 手足症候群のために, 車の運転をするのが難しい.

6. 手足症候群のために, ストッキング/タイッ( または靴下) を 12123 履くのが難しい.

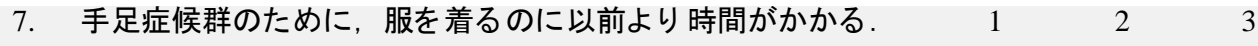

8. 手足症候群のために, 靴を履くのが難しい.

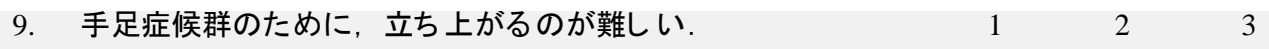

10. 手足症候群のために, 短い距離でも歩くのが難しい. $\quad 1 \quad 1 \quad 2$

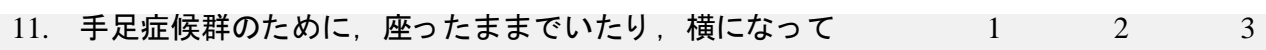
いたりすることが多い

12. 手足症候群のために, 眠りにつきにくい.

13. 手足症候群のために，仕事に支障がある.

14. 手足症候群のために, 他者との人間関係が円滑でない.

「痛みを感じない」から「想像できる範囲で最も強い痛み」までの尺度の中で, あなたの感じる痛みの程度を直 線上に印をつけて表して下さい。

痛みを感じない

想像できる範囲で

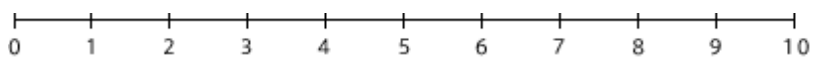

最も強い痛み 